\title{
Climate Change Vulnerability and Impacts Analysis in Kenya
}

\author{
Samwel N. Marigi \\ Institute for Meteorological Training and Research, Nairobi, Kenya \\ Email: drsmarigi@gmail.com
}

How to cite this paper: Marigi, S.N. (2017) Climate Change Vulnerability and Impacts Analysis in Kenya. American Journal of Climate Change, 6, 52-74

https://doi.org/10.4236/ajcc.2017.61004

Received: November 21, 2016

Accepted: March 4, 2017

Published: March 7, 2017

Copyright (C) 2017 by author and Scientific Research Publishing Inc. This work is licensed under the Creative Commons Attribution International License (CC BY 4.0).

http://creativecommons.org/licenses/by/4.0/

\begin{abstract}
In this paper, observed climate change impacts in the country were collated and tabulated to provide the baseline information on the prevalent climate hazards associated with the impacts. Available climate and socio-economic datasets for the country were then subjected to the GeoClim software analyses in order to generate the spatial patterns of exposure, sensitivity and adaptive capacity parameters. Composite layers of these parameters were overlayed to generate the vulnerability map. Finally, effectiveness of the country's existing policies and capacities in addressing the vulnerabilities has been evaluated. Results have revealed that the entire country is vulnerable. However, the Northern parts as well as the Southern tip of the coastal strip are the most vulnerable. Flood and drought hazards result in the greatest impacts to the Kenyan society. Significant gaps and weaknesses have been observed in the existing policies and capacities which render them inadequate to effectively address the vulnerability. It is concluded that the country urgently requires a raft of measures to address the current and future vulnerabilities presented by climate change.
\end{abstract}

\section{Keywords}

Climate Change, Hazards, Vulnerability, Impacts, GeoClim Software

\section{Introduction}

The development agenda for Kenya is being widely affected by climate change and its resultant impacts, which could cost the economy a significant percentage of the country's GDP. Thus, the cumulative impacts of climate change have the potential to reverse much of the progress made towards the attainment of the Sustainable Development Goals (SDGs) and Kenya's development blueprint-Vision 2030.

Most of the people in Kenya are vulnerable to the impacts of climate change 
because of their poverty; with about $46 \%$ of the population classified as poor [1]. The reliance of the majority of the population on rain-fed agriculture and livestock production puts them in a vulnerable position first because of the negative impacts that adverse weather conditions have on their production systems and also due to fluctuating market prices for their produce, both locally and internationally.

Mean annual rainfall in Kenya follows a bimodal seasonal pattern with the long rains generally occurring in March to May, while the short rains occur in October to December. These seasonal patterns have become unreliable resulting in frequent crop failures. Most farmers also lack relevant weather forecast data and information that would assist them to reduce their losses and/or to diversify to more suitable crops, such as drought resistant crops during the dry periods and the slow-maturing varieties when the conditions are wetter than normal.

In general, therefore, climatic fluctuations have significant impacts on Kenyan society, via agriculture, food security, water, health, natural disasters and the environment. Climate thus sits at the nexus of two principal concerns, poverty and sustainable development. For instance, extreme climate events in the country are often associated with very severe socio-economic impacts that include lack of food, water, energy, and many other basic needs including destruction of infrastructure as well as loss of lives. Such impacts have tended to retard socio-economic growth of the country with the ultimate enhancement of poverty.

Vulnerability mapping, climate monitoring, prediction and timely early warning of the extreme climate events are therefore, some of the best strategies for mitigating their negative impact on humanity, property and the environment as well as taking advantage of any positive impacts. Accurate and timely information on the characteristics of the extreme climate events including the associated vulnerabilities are, therefore, crucial inputs in sustainable development planning.

This paper, therefore, addresses the vulnerability and impacts aspects with the goal of generating knowledge necessary to inform the allocation of resources as well as developing policies and adaptation plans for vulnerable areas, sectors, groups, etc., to aid in minimizing climate change risks in the country.

"Climate change vulnerability" is the degree to which a system is susceptible to adverse effects of climate change including climate variability and extremes. It is driven by dimensions of exposure, sensitivity, and adaptive capacity. In other words, it is a function of these three parameters as presented in Equation (1) and empirically in Equation (2).

$$
V=f(E, S, A)
$$

where:

$V=$ Vulnerability to climate change,

$E=$ Exposure to climatic stimuli,

$S=$ Sensitivity to climatic stimuli,

$A=$ Adaptive Capacity. 


$$
V=E \times S-A \text {. }
$$

\section{Objective, Scope and Data}

\subsection{Objective}

The overall objective of this paper was to undertake an assessment of the vulnerability and impacts of climate variability and climate change in Kenya. This entailed the assessment and mapping of climate related natural hazards and the associated impacts as well as vulnerability to the current and projected climate change on various populations and socio-economic services in the country.

The specific objectives included:

1) Gather and document information on prevalent climate related hazards in the country.

2) Document sectoral impacts (physical, human, structural and socio-economic) of the identified hazards.

3) Determine the vulnerability of the country to the climate induced hazards.

4) Identify any existing gaps (in policies and capacities) which may be contributing to these vulnerabilities.

5) Recommend appropriate mechanisms/strategies for addressing the vulnerabilities in the country.

\subsection{Scope of the Study}

The climate change vulnerability and impacts assessment covered the entire country including the following five sectors which are crucial in the socio-economic development of the country:

1) Agriculture and food security.

2) Water, aquatic ecosystems and infrastructure.

3) Health including sanitation and Human settlements.

4) Terrestrial ecosystems including forestry and tourism.

5) Energy and infrastructure.

\subsection{Data}

Two types of data sets were used in this assessment namely:

1) Climate data: Point rainfall data covering the period 1960 to 2014 . The data was for 39 synoptic meteorological stations spread over the country and was obtained from the Kenya Meteorological Department (KMD). This dataset was used to determine the exposure parameters.

2) Socio-economic data: Population density statistics; Poverty indices; access to improved sanitation; Literacy levels; and Access to Health Infrastructure. This data was for all the 47 counties of Kenya and was obtained from the Commission on Revenue Allocation [2]. The data set was used to determine Sensitivity and Adaptive capacity parameters.

It is pointed out here that many parameters determine both sensitivity and adaptive capacity of systems. However, data on majority of these parameters in 
the country was either inadequate for analysis or unavailable. The analysis was therefore, based on the few parameters with adequate data available. Interpretation of the results is therefore solely based on these parameters but is a useful first hand piece of information for policy and decision makers addressing climate change vulnerability issues in the country.

\section{Methodology}

\subsection{Desktop Review as Well as a One to One Interview (via Phone and Skype) with County Directors of Meteorology and County Heads for Environment}

This review was aimed at gathering information on prevalent climate related hazards, associated impacts, as well as current challenges/gaps in addressing risks posed by the climate change hazards. It was based on Journals and articles relevant to this topic of study as well as relevant case studies, projects, programs undertaken in the country including policy and regulatory documents of the country.

\subsection{Vulnerability Analysis}

This was undertaken by the use of the GeoCLIM Software [3]. GeoCLIM is a spatial analysis tool designed for climatological analysis of historical rainfall and temperature data. The GeoCLIM provides an array of accessible analysis user friendly tools which can be used to obtain and analyze climate data, analyze seasonal trends and/or historical climate data, create visual representations of climate data, create scripts (batch files) to quickly and efficiently analyze similar "batches" of climate data, view and/or edit shape files and raster files, and extract statistics from raster datasets to create time series. Details of the software are available at http://chg-wiki.geog.ucsb.edu/wiki/GeoCLIM.

\subsubsection{Treatment of the Climate Data}

Five exposure parameters have been computed namely: mean annual rainfall totals, mean annual decadal rainfall changes, mean annual rainfall trends, mean annual Standardized Precipitation index (SPI) and mean annual coefficient of rainfall variability. Layers of the spatial characteristics of each of the exposure parameters over the country have then been generated.

\subsubsection{Treatment of the Socio-Economic Data}

Available sensitivity parameters data (population density, poverty indices and access to improved sanitation) has been tabulated for the representative county points followed by the generation of layers of the spatial characteristics of each of these sensitivity parameters. The available adaptive capacity parameters data (literacy levels, access to health infrastructure) have also been subjected to the same procedure to generate the respective spatial layers.

\subsubsection{Vulnerability Mapping}

Vulnerability mapping of the elements has been effected on the composite spatial indices of vulnerability developed based on spatial data layers representing 
the different components of vulnerability (exposure, sensitivity and lack of adaptive capacity). These indices are produced based on averaging/adding normalized indicators (i.e. Variables whose value ranges have been standardized in order to make them comparable to one another). The components of the vulnerability index were as follows:

1) Exposure = sum (all exposure input variables), giving the overall exposure layer.

2) Sensitivity = sum (all sensitivity variables), giving the overall sensitivity layer.

3) Adaptive Capacity = sum (all adaptive capacity variables) giving the overall adaptive capacity layer.

The index of overall vulnerability is then given as:

4) Vulnerability = exposure + sensitivity + lack of adaptive capacity.

The final generation of the maps was effected by importing and mapping components and overall vulnerability index using the ArcGIS software.

\section{Literature Review}

A number of studies have been undertaken in the country that are related to the current study but have not adequately addressed the issue of climate change vulnerability and impacts assessment, which is the subject of this paper.

Climate Network Africa [4] has documented the potential impacts of climate change in Kenya in a number of sectors including: energy, water resources, biodiversity, forests, wildlife and tourism, agriculture, and human health.

The Drought Monitoring Centre-Nairobi (DMCN) [5] undertook a project on factoring of weather and climate information into disaster management policy in Kenya with a view to reducing the impacts and vulnerabilities of various socioeconomic sectors to climate induced hazards. These sectors included water resources; agriculture and food security; natural resources, environment, forestry, tourism and wildlife; human settlement, health and public safety; energy, industry, transport and communication. The report has documented sectoral vulnerabilities, identified gaps and recommended strategies to integrate climate/ weather into development planning policies so as to make the country resilient to the real and perceived weather/climate change shocks. Traditional climate monitoring and prediction methods continue to contribute significantly to the management of the various climate related activities in Kenya, thus contributing to the resilience of some communities to climate related shocks.

DMCN [6] undertook a pilot project to understand how communities in Western Kenya use indigenous methods to detect the vulnerable periods to climate shocks and the management practices that ensure resilience of the communities. The project was intended to build a partnership between the climate scientists and traditional climate forecasters and rainmakers in Kenya with a view to improving the dissemination and application of climate outlooks in the country so as to enhance resilience. The report has useful information for understanding the traditional methods used not only for predicting seasonal rains, but also for mana- 
ging associated disasters.

A Drought Post-Disaster Needs Analysis (PDNA) was conducted in Kenya [7] at the request and direction of the Ministry of Finance with technical support from the European Union, United Nations, and World Bank. The aim of this assessment has been to develop a quantitative estimation of the impact of the drought on the socio-economic development of the country and recommendations of immediate recovery and long-term resilience-building in the country. The findings that have emerged show, in no uncertain terms, Kenya's vulnerability to droughts in which the country has experienced drought of varying intensities across various areas.

A World Bank report [8] which is a flagship product of the Africa Water Resources Management Initiative (AWRMI) prepared with the support of the Kenya Country Team, Mainstreaming Fund for the Environment, the Bank Netherlands Water Partnership Program, World Bank Institute and Environment Department, and SIDA - is a critical step in the World Bank's policy dialogue on water resources management reforms and investment planning that was at the time being promoted by the Government of Kenya through the Ministry of Water and Irrigation. The report represents a pioneering attempt by the AWRMI to focus on the economic implications of water resource management in Kenya (and indeed in Africa), looking specifically at two of the most important water-related issues that make the economy and people of Kenya highly vulnerable-the effects of climate variability and the steady degradation of the nation's water resources. In both areas, the report finds significant economic impacts on water resources by both drought and floods-a very serious drag on the country's economic performance.

A study on the "Economics of Climate Change in Kenya" [9] funded by DFID and DANIDA and undertaken by the Stockholm Environment Institute (led by the Oxford Office, in conjunction with the SEI office in Nairobi) together with international and local partners, has assessed the impacts and economic costs of climate change, the costs and benefits of adaptation and pathways of low carbon growth for Kenya on a number of sectors including coastal zones; agriculture; energy; health; extreme events; water resources; and ecosystem services. The outcome of the study provides the following key messages for the country:

1) Existing climate variability has significant economic costs in Kenya.

2) Future climate change will lead to additional and potentially very large economic costs.

3) Adaptation can reduce the economic impacts of climate change but it has a cost. The costs of adaptation are still emerging and are uncertain. However, this does not mean that no action should be taken. Instead it requires more robust strategies.

The Kenya Government and DMCN [10] undertook a study to enhance the capacity of the country to manage and cope with flood related disasters. The country had identified that there was a need to assess the vulnerability of the population living in the flood prone areas of Kenya, develop risk zone maps, review, collate 
and synthesize all studies/activities related to flooding in western Kenya and also to examine the reasons for continued flooding despite numerous past studies/activities among others.

Mombasa city has a long history of frequent natural disasters associated with extreme climatic events. A GIS based study [11], provides a first quantitative estimate, both now and through the 21st century, of the number of people and associated economic assets exposed to coastal flooding due to sea level rise and storm surges. It gives a good indication of the potential impacts that the city might experience and indicates the magnitude of impacts which need to be considered in planning decisions. The analysis shows that the projected socioeconomic change and the location of population growth play a significant role in the overall increase in population and asset exposure to extreme water levels. This study concludes that significant numbers of people in Mombasa are, and will continue to be, vulnerable to flooding due to extreme water levels during this century. However, forward planning to address projected population growth can reduce exposure levels to a significant degree. Appropriate adaptation measures, such as the construction of defenses, can be expected to reduce the flooding risk but this was not considered as part of this study.

Otiende [12] has undertaken a case study to assess the physical and economic impacts of climate change hazards with a focus on riparian floods and estimated cost of adapting to the present and future flood risk in Kenya. The study attempted to quantify the economic cost of actual impacts and the losses accrued from the deviation from likely economic activity as a result of specific flood events within the decade 1997-2008. The 1997/98 El Niño and the 2006 flood events associated with widespread impacts across the country were considered. The geographical focus of the study was the Budalang'i and Kano flood plains in Lake Victoria Basin (LVB) in western Kenya and Tana River flood plains in the southeastern part of the country. The study has revealed that the high vulnerability to flood risk in western Kenya is as a result of high poverty rates, poor land use patterns (deforestation and settling and cultivating along riverbanks), low education and illiteracy levels and the state of infrastructure that is in neglect.

\section{Results and Discussions}

In this section, results are systemically presented and discussed on the basis of the objectives already outlined.

\subsection{Situational Analysis}

\subsubsection{Baseline Information}

Kenya experiences a number of natural hazards, the most common being weather related. These are, on their own, not harmful. However when these natural hazards interact with people and systems, they are likely to cause damage of varying magnitude resulting in a disaster. Disasters thus occur when the natural hazards interact with vulnerable people, property, and livelihoods causing varying damage depending on the level of vulnerability of the individual, group, prop- 
erty or livelihoods as summarized in Table 1(a) below for hazards commonly experienced in the country.

Table 1(b), on the other hand, provides a list of areas in the country considered hotspots for occurrence of these hazards.

Table 1. (a) Common hazards in Kenya that lead to disasters. (b) Climate hazards hotspots in Kenya.

(a)

\begin{tabular}{|c|c|c|}
\hline Hazard & Vulnerable elements & Impacts \\
\hline Droughts & $\begin{array}{l}\text { Crops, lives, } \\
\text { water resources }\end{array}$ & Deaths and loss of livelihoods \\
\hline Floods & $\begin{array}{l}\text { Crops, lives, } \\
\text { infrastructure }\end{array}$ & $\begin{array}{l}\text { Loss of lives, disruption of economic activities, } \\
\text { lowering of water quality, etc. }\end{array}$ \\
\hline Landslides & $\begin{array}{l}\text { Lives, infrastructure, } \\
\text { crops }\end{array}$ & $\begin{array}{l}\text { Loss of lives, loss of livelihood and disruption } \\
\text { of social set-ups }\end{array}$ \\
\hline Hailstones & Crops, lives & Deaths, injuries and loss of livelihoods \\
\hline $\begin{array}{l}\text { Thunderstorms and } \\
\text { lighting strikes }\end{array}$ & $\begin{array}{l}\text { Lives and } \\
\text { infrastructure }\end{array}$ & $\begin{array}{l}\text { Deaths, injuries and disruption of economic } \\
\text { activities }\end{array}$ \\
\hline Strong winds & $\begin{array}{l}\text { Lives, property, } \\
\text { water transport }\end{array}$ & $\begin{array}{l}\text { Loss of lives, livelihoods and disruption of } \\
\text { water transport activities }\end{array}$ \\
\hline Frost & Crops & Loss of livelihoods \\
\hline $\begin{array}{l}\text { Extreme } \\
\text { temperatures }\end{array}$ & Crops and lives & $\begin{array}{l}\text { Loss of livelihood as well as impairments of } \\
\text { human health }\end{array}$ \\
\hline Fog & $\begin{array}{l}\text { Both road and } \\
\text { air transport }\end{array}$ & $\begin{array}{l}\text { Loss of lives through accidents and disruption } \\
\text { of air and road transport activities }\end{array}$ \\
\hline Wild fires & Lives and property & Deaths, injuries and loss of livelihoods \\
\hline
\end{tabular}

(b)

\begin{tabular}{|c|c|}
\hline Hazard & Areas most affected (hotspots) \\
\hline Droughts & Counties in Eastern, North Eastern, coast, and parts of Rift Valley \\
\hline Floods & $\begin{array}{l}\text { Budalangi, Nyando, Homa Bay areas (all within the Lake Victoria } \\
\text { Basin) and Tana River county in the lower Tana River catchment }\end{array}$ \\
\hline Flash floods & $\begin{array}{l}\text { Mainly in urban centers like Nairobi and Mombasa due to poor } \\
\text { drainage and uncontrolled urban settlements. This type of flooding } \\
\text { is also experienced in Arid and semi-arid areas particularly northern } \\
\text { and north-eastern parts of the country }\end{array}$ \\
\hline Landslides & $\begin{array}{l}\text { Central Kenya and around Mount Kenya region mainly in Muranga } \\
\text { and parts of Meru counties }\end{array}$ \\
\hline Hailstones & $\begin{array}{l}\text { Localised areas countrywide but with highest concentration within } \\
\text { the Lake Victoria Basin }\end{array}$ \\
\hline $\begin{array}{l}\text { Thunderstorms and } \\
\text { lighting strikes }\end{array}$ & $\begin{array}{l}\text { Localised areas countrywide but with highest concentration in Kisii } \\
\text { and Kakamega counties in Western Kenya }\end{array}$ \\
\hline Strong winds & $\begin{array}{l}\text { Localised areas countrywide but with highest concentration in } \\
\text { northern Kenya counties }\end{array}$ \\
\hline Frost & $\begin{array}{l}\text { Vary rare phenomenon but occasionally experienced around } \\
\text { Nyahururu area within the slopes of the Aberdare mountain Range }\end{array}$ \\
\hline Extreme temperatures & Northern Kenya counties \\
\hline Fog & $\begin{array}{l}\text { Localised areas countrywide but with highest concentration around } \\
\text { Limuru, Kinungi and Timbora, all along the Nairobi to Eldoret Highway }\end{array}$ \\
\hline
\end{tabular}


It should be pointed out here that floods and drought are the most common hazards in the country and result in the greatest impacts to society.

\subsubsection{Documented Impacts Including Economic Costs}

The impacts are assessed with reference to the sectors provided in the scope of this study. It is noted that specific in-depth assessment of impacts has not been systematic in the country. It is undertaken on an Ad hoc basis, in form of case studies and targeting one or few of the sectors depending on the funding level and also the interest of the donor of the funds. As a consequence, the results presented here relate only to those assessments that have been carried out in the country and relate to any of the sectors as depicted in Tables 2-5.

1) Agriculture and food security including livestock and fisheries.

2) Water resources sector.

3) Public health, infrastructure and agriculture.

4) Across sectors (agriculture, livestock, aquatic systems, forestry, industry and water supply).

It is evident from Tables 2-5 that droughts and floods occurrences in the country have always resulted in enormous economic losses in addition to destruction of property as well loss of lives and livelihoods.

\subsection{Vulnerability Assessment}

\subsubsection{Determinants of Vulnerability}

Based on the method of determining vulnerability as described in Section 3.2, the following parameters were computed:

\section{Exposure parameters}

1) Mean annual total rainfall.

2) Mean coefficient of annual rainfall variability.

3) Mean annual rainfall trend.

4) Mean annual Decadal rainfall changes (2001-2012 minus 1981-2000).

Table 2. Estimated economic loss from livestock deaths due to 1999-2000 drought stress [13].

\begin{tabular}{lccc}
\hline \multicolumn{1}{c}{ Attribute } & Small stock & Cattle & Camels \\
\hline Northern Kenya rangelands & $43 \%$ of total & $35.2 \%$ of total & $18 \%$ of total \\
Southern Kenya rangelands & $16 \%$ of total & $25 \%$ of total & Negligible \\
$\%$ average mortality & $29.5 \%$ of total & $30.1 \%$ of total & $18 \%$ of total \\
Total animals at risk & 8 million & 3 million & 80,000 \\
Likely No. lost & $2,360,000$ & 903,000 & 14,400 \\
$\begin{array}{l}\text { Average price per animal } \\
\text { during drought }(\mathrm{Ksh})\end{array}$ & 500 & 5000 & 6500 \\
Total loss $($ Ksh) & 1.18 billion & 4.52 billion & 93.6 million \\
Total loss $(\$)$ & 15.73 million & 60.2 million & 1.25 million \\
Grand total loss $($ Ksh) & & 5.8 billion & \\
Grand total loss $(\$)$ & & 77.3 million & \\
\hline
\end{tabular}


Table 3. Estimated flood damage costs to the water sector during the $1997 / 98$ floods [14].

\begin{tabular}{|c|c|c|}
\hline District & Type of services affected & Cost (millions of Ksh) \\
\hline Wajir & Dams and pans silted up & 95 \\
\hline Garissa & Dams and pans silted up & 144 \\
\hline Mandera & Dams and pans silted up & 63 \\
\hline Lamu & Dams and pans silted up, water pipeline destroyed & 48 \\
\hline Malindi & Dams and pans silted up, water pipeline destroyed & 16 \\
\hline TaitaTaveta & Dams/pans silted up & 9 \\
\hline Kilifi & Dams/pans silted up, some destroyed & 26 \\
\hline Tana River & Dams and pans damaged & 63 \\
\hline Kwale & Dams/pans silted up, water pipelines damaged & 58 \\
\hline Kisumu & Dams/pans silted up or damaged, water pipelines damaged & 11 \\
\hline Suba & Dams/pans silted up or damaged, water pipelines damaged & 19 \\
\hline Rachuonyo & Dams/pans silted up or damaged, water pipelines damaged & 9 \\
\hline Busia & Dams/pans silted up or damaged, water pipelines damaged & 63 \\
\hline Isiolo & Earth dams/pans destroyed & 42 \\
\hline Makueni & Earth dams/pans destroyed & 34 \\
\hline Mwingi & Earth dams/pans destroyed & 11 \\
\hline Moyale & Dams and pans silted up, some destroyed & 29 \\
\hline Marsabit & Earth dams/pans destroyed & 29 \\
\hline Baringo & Dams/pans silted up, water distribution network damaged & 134 \\
\hline Keiyo & Earth dams/pans destroyed & 16 \\
\hline Marakwet & Dams and pans silted up & 11 \\
\hline Samburu & Dams and pans silted up & 26 \\
\hline Kwale & - & 28 \\
\hline Kilifi & - & 220 \\
\hline Total (22 disricts) & & 1200 \\
\hline
\end{tabular}

Table 4. Costs arising from 1997-1998 El Niño-induced floods [14].

\begin{tabular}{llc}
\hline \multicolumn{1}{c}{ Effects } & \multicolumn{1}{c}{ Associated costs } & Estimated cost ('000,000) Ksh \\
\hline Damage to infrastructure & Water systems & 3600 \\
& Road network, communication and buildings & 62,000 \\
Public health hazard & Treatment costs & 4500 \\
Loss of crops & Crop loss/reduced production & 33 \\
Total & & 70,000 \\
\hline
\end{tabular}


Table 5. Costs arising from 1998-2000 La Niña drought [15].

\begin{tabular}{llc}
\hline \multicolumn{1}{c}{ Effects } & \multicolumn{1}{c}{ Associated costs } & Estimated cost ('000,000) Ksh \\
\hline Loss of crops & (a) Crop loss & 19,000 \\
& (a) Livestock deaths & 5800 \\
Loss of livestock & (b) Veterinary costs & 93 \\
& (c) Reduced livestock production & 5100 \\
Forest fires & (d) Conflict management & 6 \\
Damage to fisheries & (a) Forest destruction and damage & 29 \\
Reduced hydropower generation & (a) Reduced aquaculture production & 19 \\
Reduced industrial production & (a) Increased cost of generation & 51,000 \\
& (b) Increased import substitutes & 806 \\
Water supply & (a) Loss of production & 110,000 \\
& (a) Increased water collection time-ASALs & 5100 \\
Total & (b) Increased water collection time-Nairobi & 4400 \\
\hline
\end{tabular}

5) Mean Annual Standardized Precipitation index.

\section{Sensitivity parameters}

1) County population densities.

2) County poverty indices.

3) County population access to improved sanitation.

\section{Adaptive parameters}

1) County literacy levels (population that can read and write).

2) County population access to healthcare facilities.

The spatial patterns of these parameters as generated by the GeoCLIM software are presented in Figures 1(a)-1(n). Figures 1(a)-1(f) are patterns of exposure parameters while Figures $1(\mathrm{~g})-1(\mathrm{j})$ represent the patterns of sensitivity parameters. Figures $1(\mathrm{k})-1(\mathrm{~m})$ are patterns of lack of adaptive capacity. Figure $1(n)$ represents the country vulnerability as a consequence of climate variability and change.

The composite of Figures 1(a)-1(e) is Figure 1(f) which is the overall exposure in the country. From Figure 1(f), it is observed that much of northern, eastern, southeastern and the southern tip of coastal Kenya has high exposure to climate induced hazards compared to the rest of the country. This translates to high exposure of people property and livelihoods in these areas.

The composite of Figures $1(\mathrm{~g})-1(\mathrm{i})$ is Figure $1(\mathrm{j})$ which is the overall sensitivity in the country. It is observed from the figure that much of northern and southern coast of the country has high sensitivity to climate induced hazards compared to the rest of the country.

The composite of Figures $1(\mathrm{k})-1(\mathrm{l})$ is Figure $1(\mathrm{~m})$ which is the overall lack of adaptive capacity in the country. It is observed from the figure that much of 


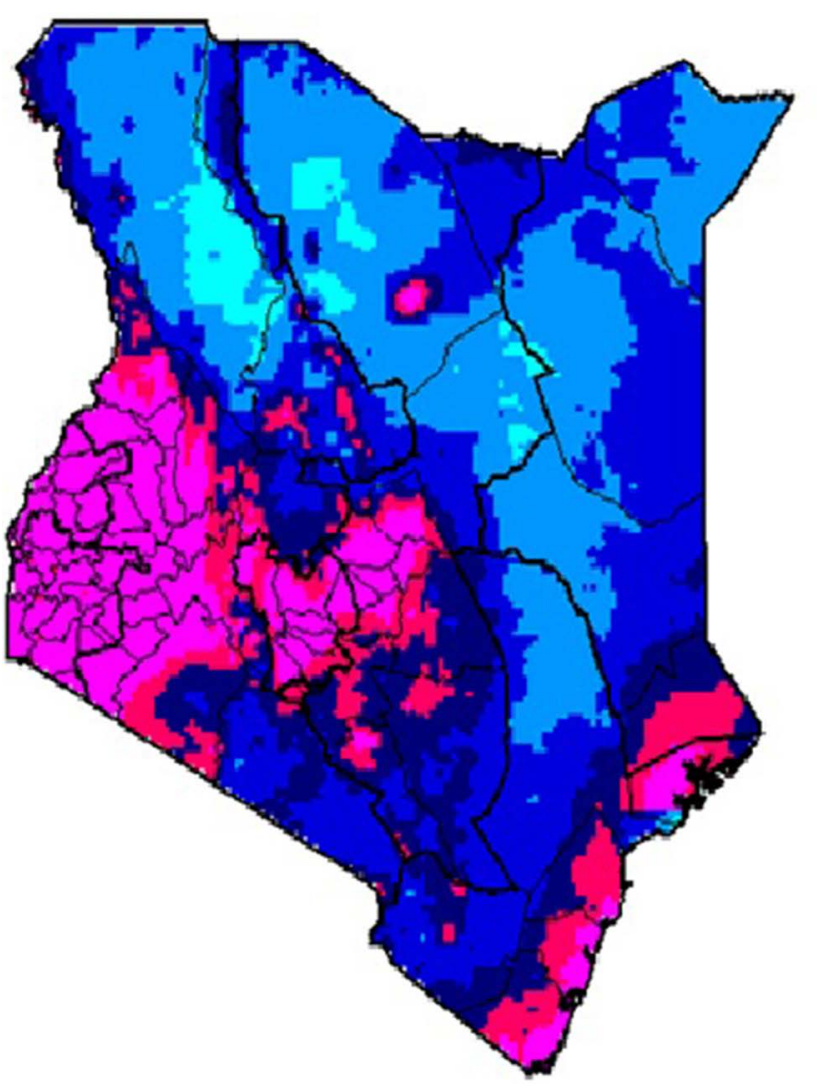

Avgannual ppt (mm)

\begin{tabular}{|l|l}
\hline & $0-50$ \\
& $-51-100$ \\
$101-200$ \\
\\
$201-400$ \\
$\square$ \\
$401-600$ \\
$601-800$ \\
$801-1000$ \\
$\square>1000$
\end{tabular}

(a)

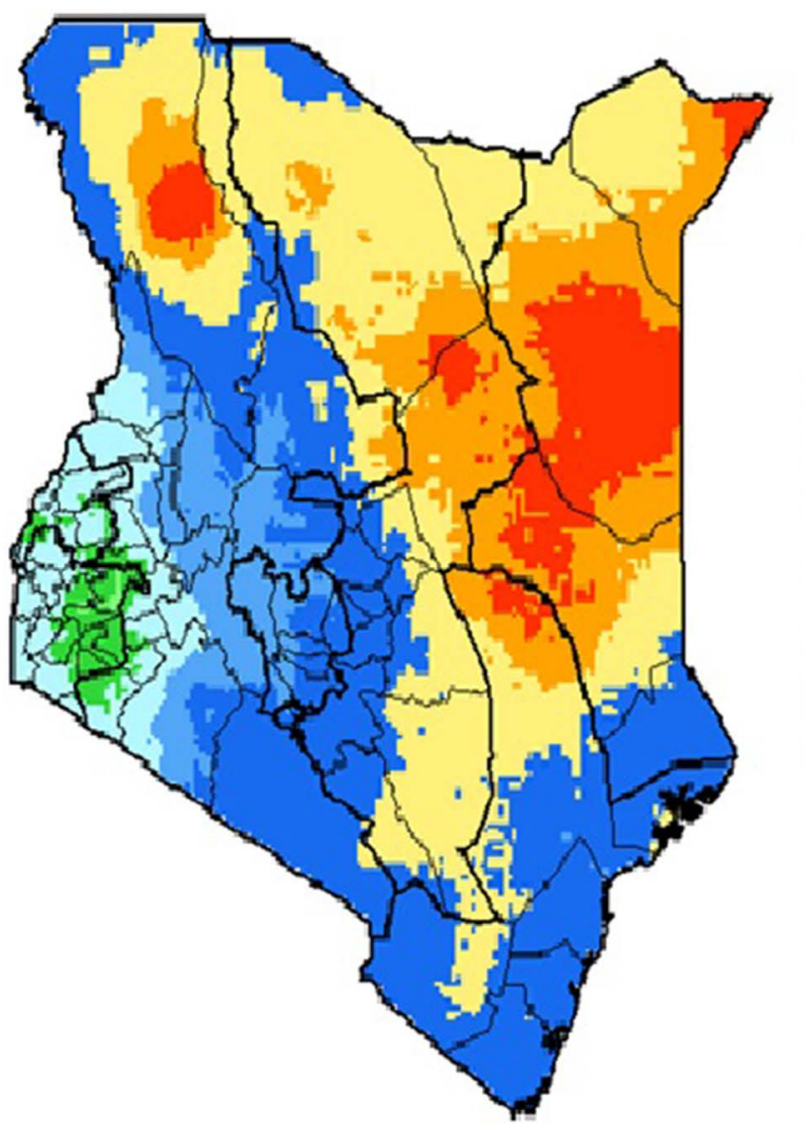

Avgannual ppt cv (\%)

$\square 0-2$

$\square-4$

$5-6$

$7-8$

$9-10$

$11-15$

$16-20$

$21-30$

$31-40$

$41-50$

$>50$

(b) 


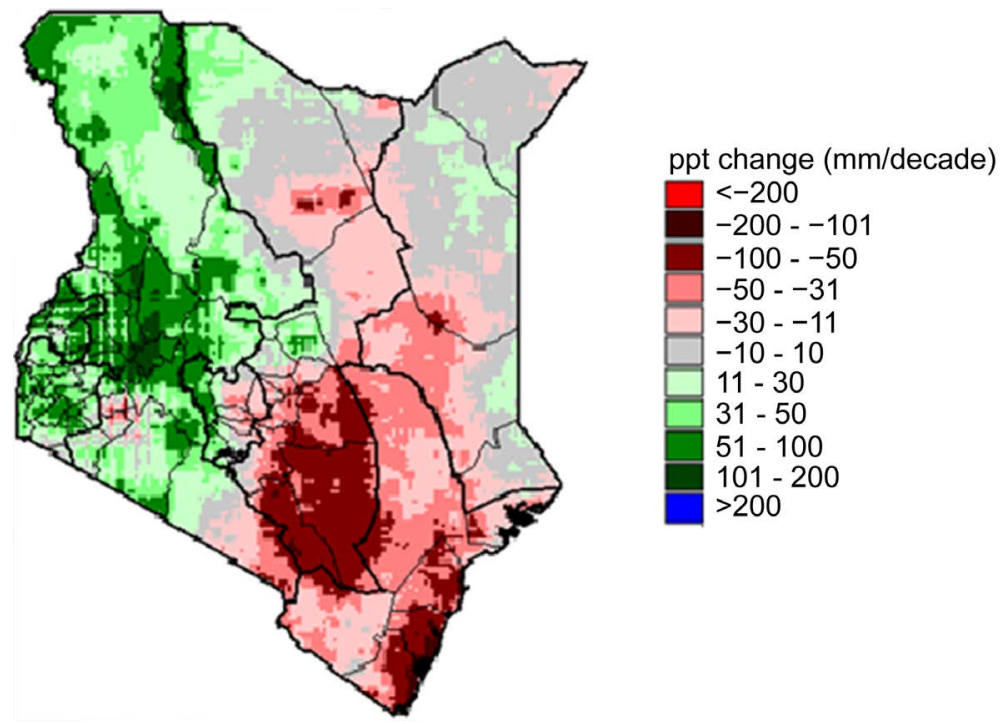

(c)

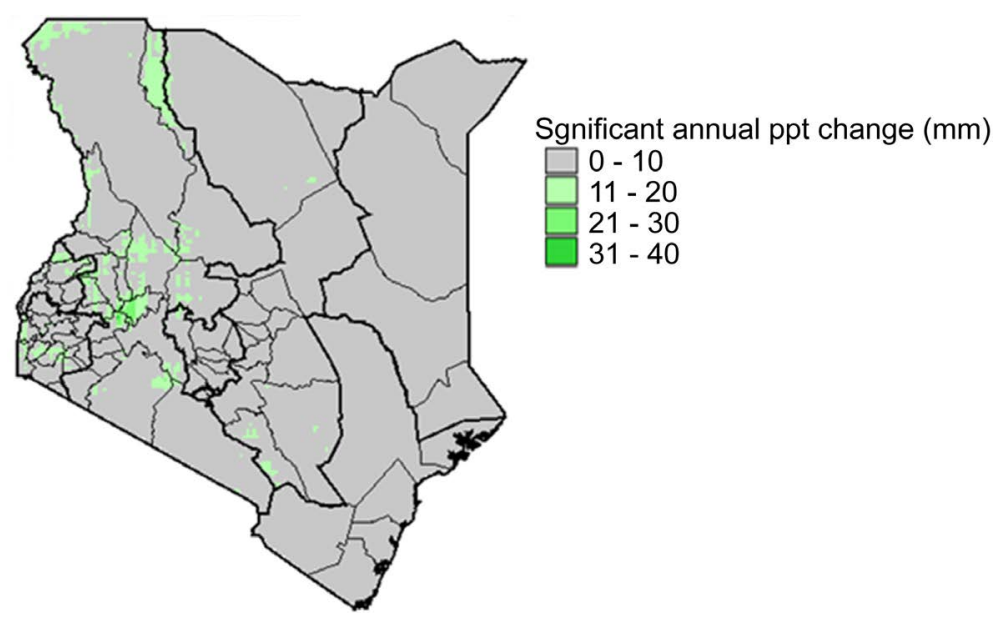

(d)

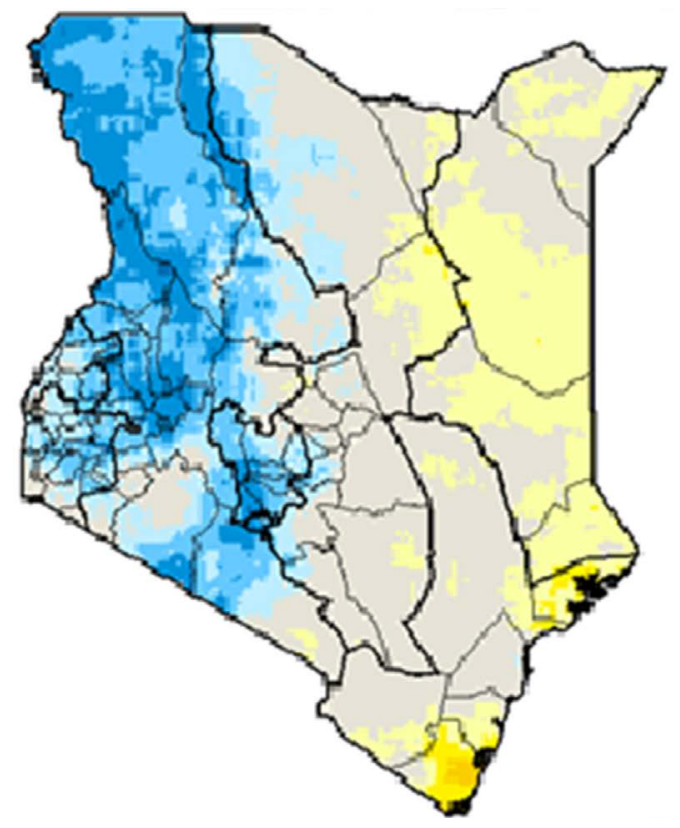

Annual SPI

$2-2.5$

$1.5-2.0$

$1.0-1.5$

$0.5-1.0$

$-0.5-0.5$

$-1.0--0.5$

$-1.5--1.0$

$-2.0--1.5$

(e) 


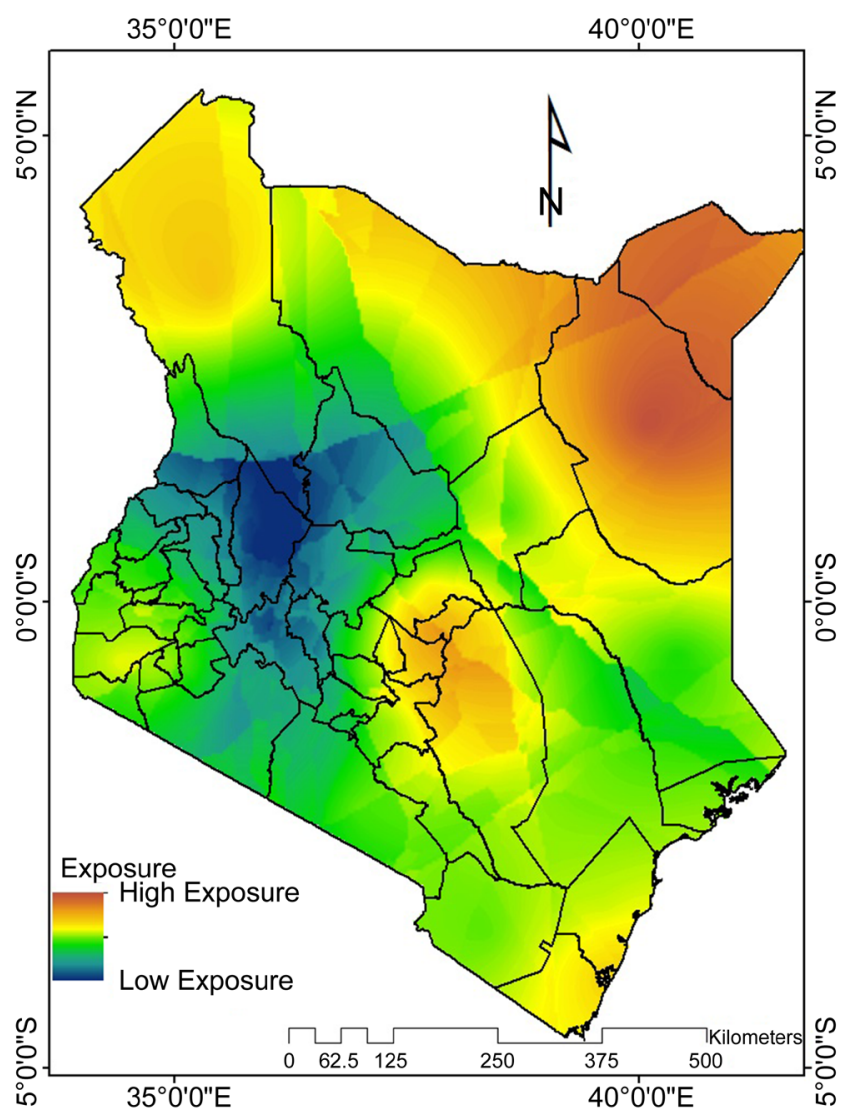

(f)

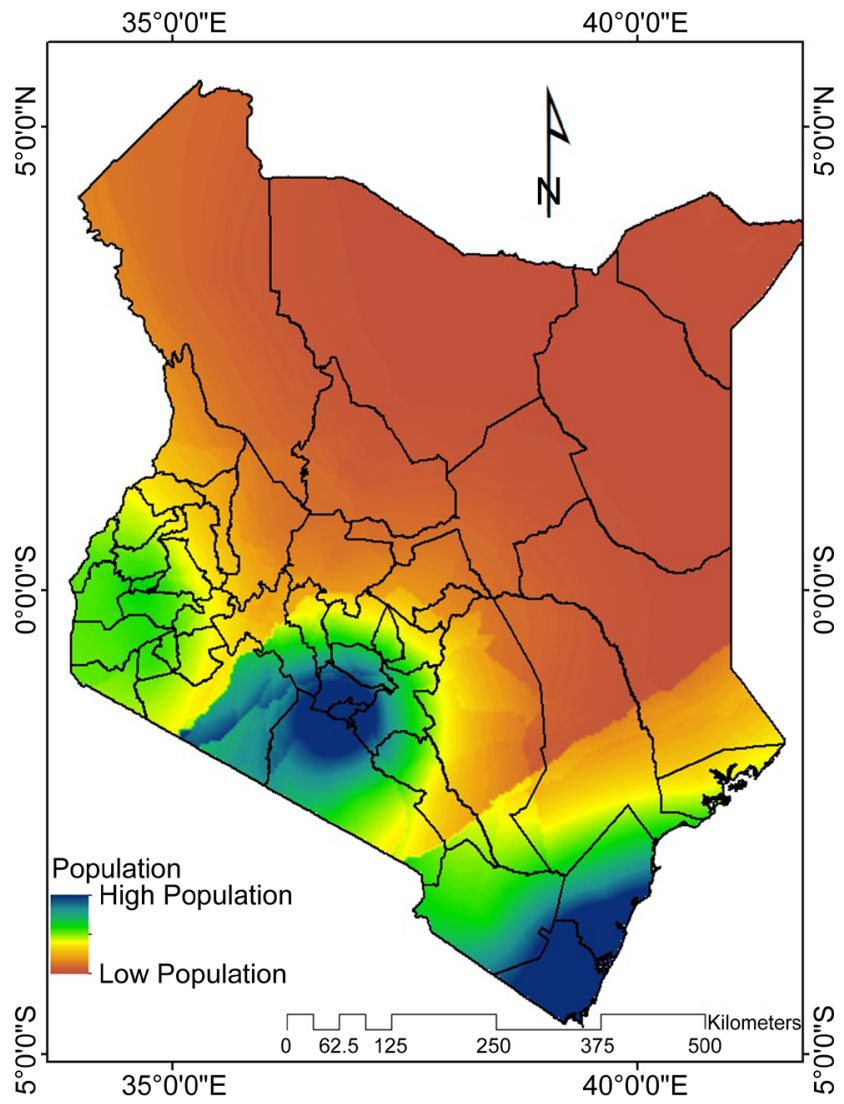

(g) 


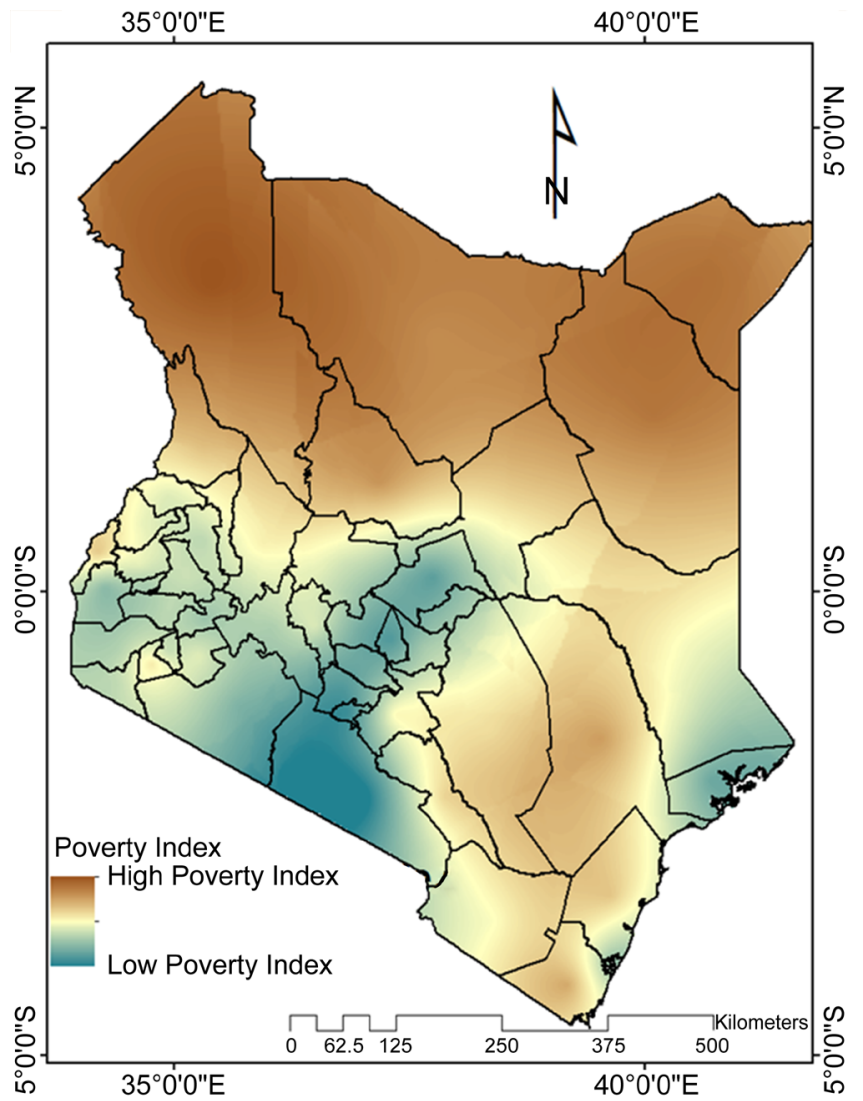

(h)

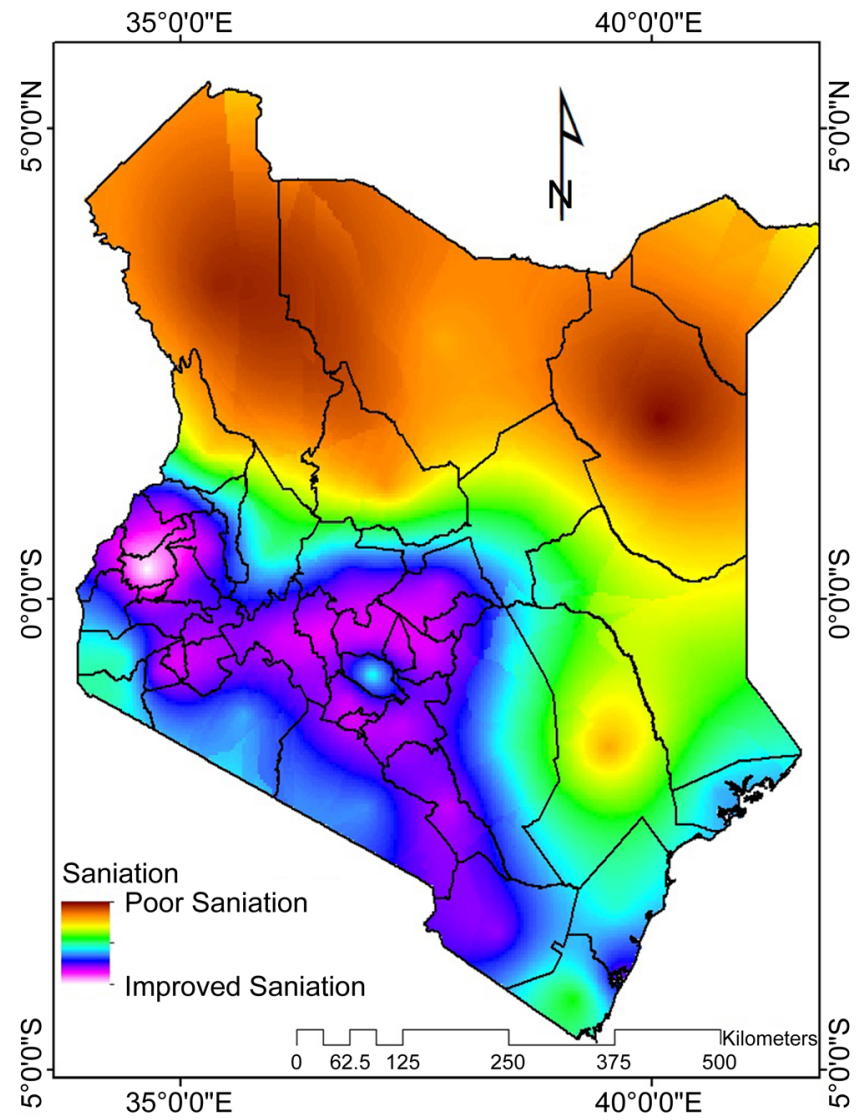

(i) 


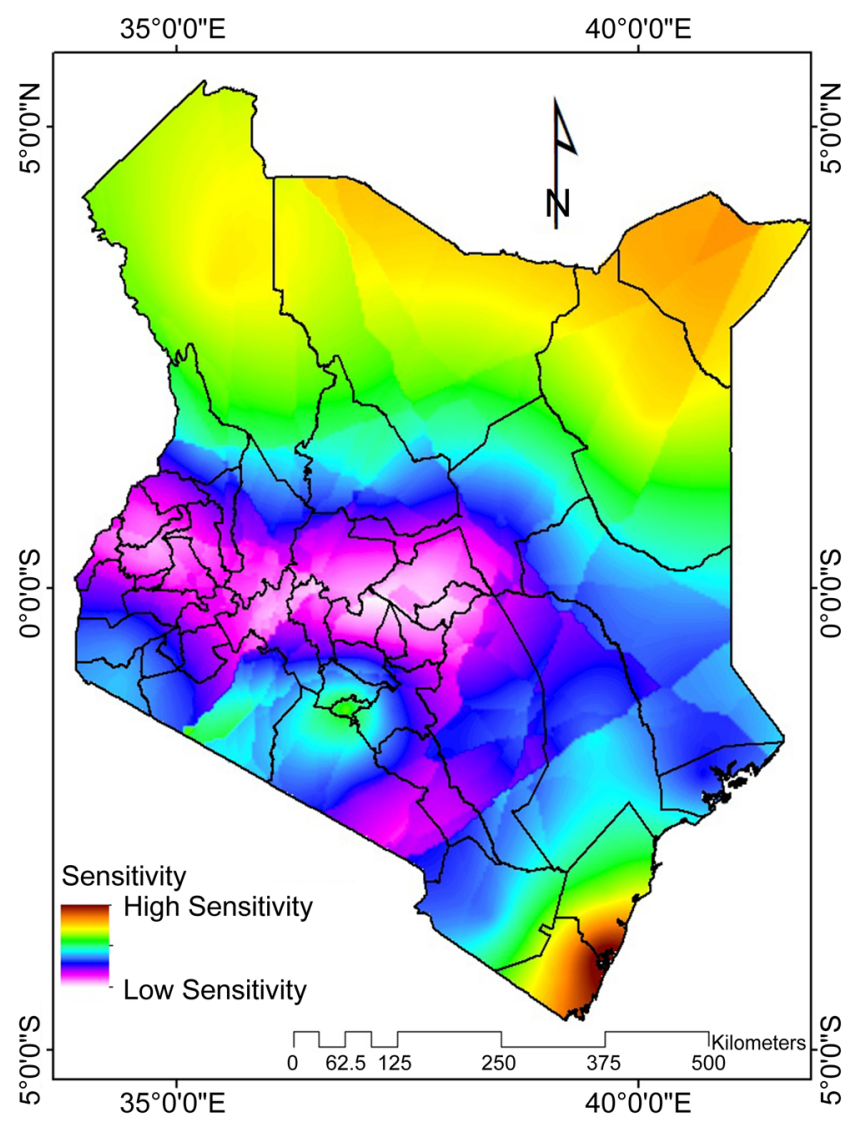

(j)

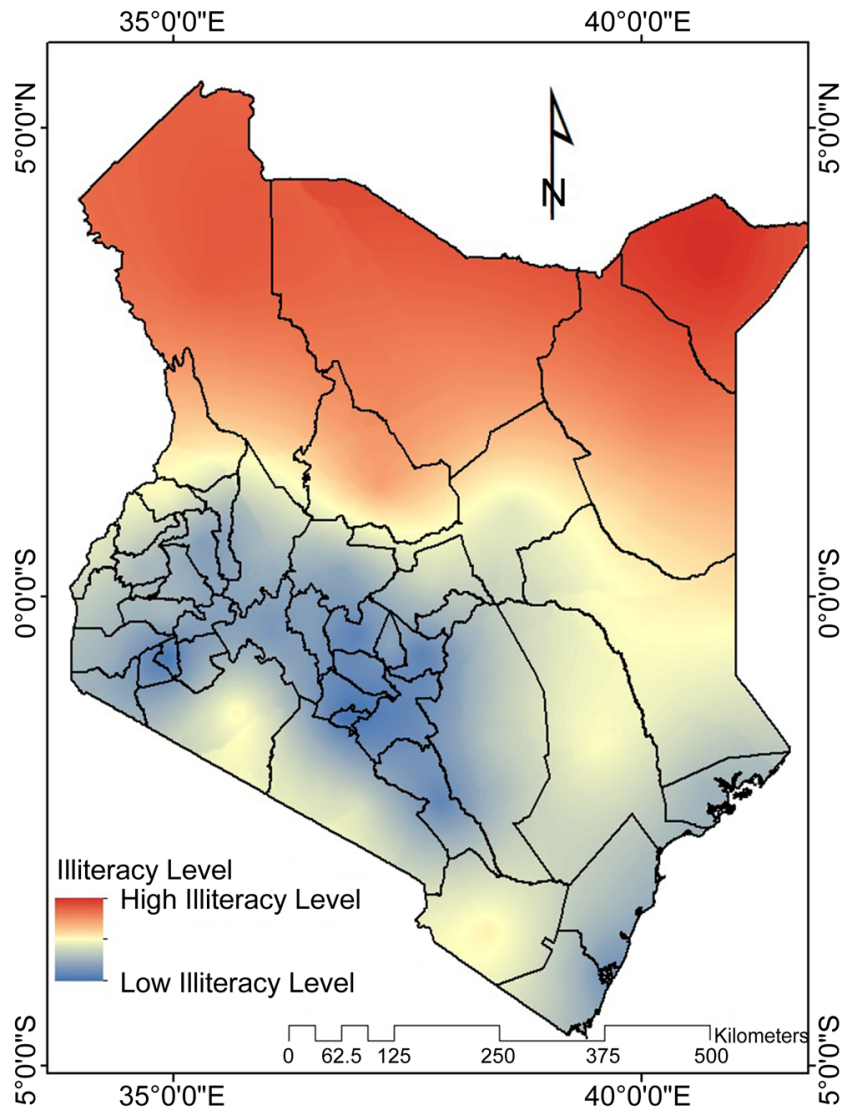

(k) 


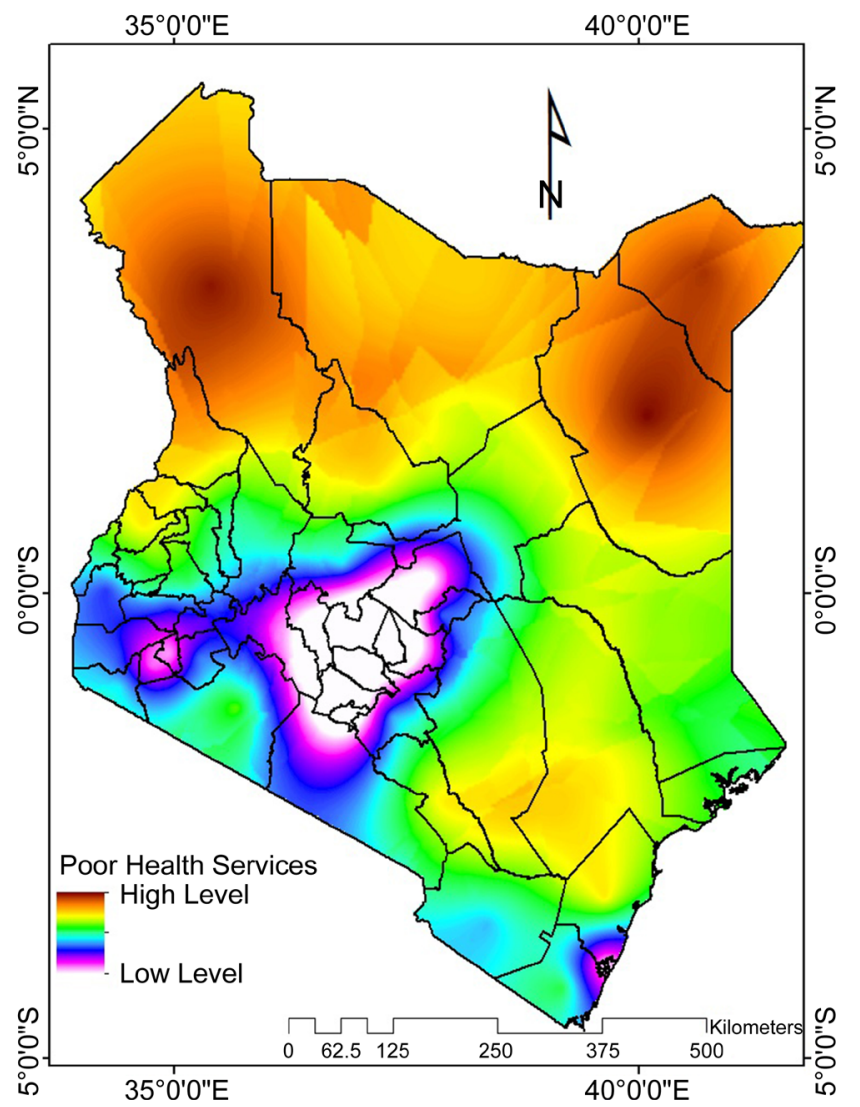

(I)

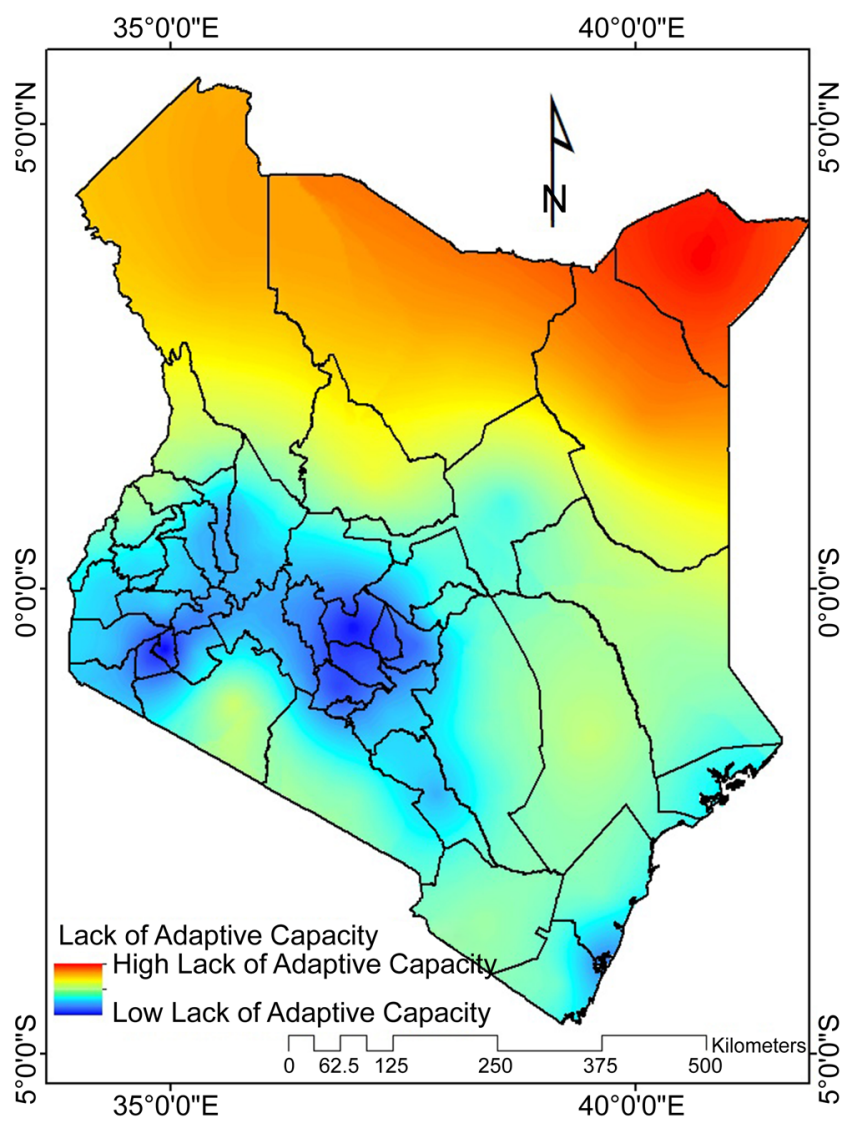

(m) 


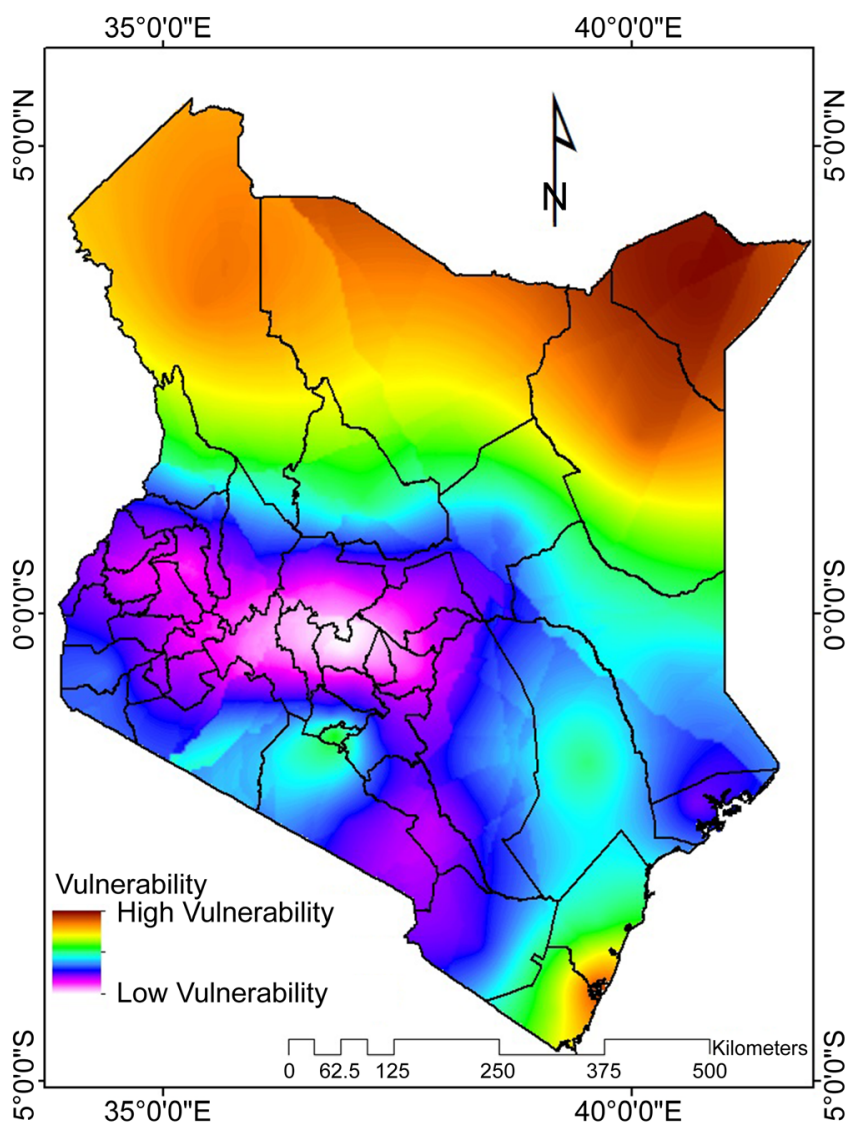

(n)

Figure 1. (a) Mean annual rainfall total (mm); (b) Mean annual coefficient of rainfall variability (\%); (c) Mean annual decadal rainfall change (2001-2014 MINUS 1981-2000); (d) Mean Annual rainfall trend; (e) Mean annual Standardized Precipitation Index (SPI); (f) Overall country exposure; (g) Country Population density; (h) Country poverty index; (i) Country population access to improved sanitation; (j) Overall country sensitivity; (k) Country population Illiteracy level; (l) Country population access to health facilities; (m) Overall country lack of adaptive capacity; (n) Country vulnerability.

northern Kenya has the least capacity to adapt to climate induced hazards compared to the rest of the country.

The county's vulnerability (Figure $1(\mathrm{n})$ ), is the composite of overall country exposure, overall country sensitivity and overall country lack of adaptive capacity (Figure $1(f)$, Figure $1(j)$, Figure $1(m)$ ). It is observed from this figure that much of northern Kenya and southern tip of the coastal strip are highly vulnerable to climate induced hazards compared to the rest of the country. This translates to high vulnerability of people, property and livelihoods in these areas. Central and Western Kenya exhibit the least vulnerability.

\subsubsection{Sectoral Vulnerabilities}

It has been established in this study that floods and drought are the common hazards in the country that account for the greatest impacts to society. Excess 
(floods) or deficits (drought) of rainfall are, therefore, the climate extremes considered as contributing to the vulnerabilities in all the five sectors which are crucial to the socio-economic development of the country. Table 6 provides a summary of the likely impacts on these sectors as a consequence of the climate change vulnerabilities. The information is necessary with regard to the formulation of policies and strategies to moderate or minimize the impacts.

Table 6. Sectoral vulnerabilities.

\begin{tabular}{|c|c|c|}
\hline Extreme Event & Sector & Likely physical impacts in the various regions as a result of vulnerability \\
\hline & \multirow{6}{*}{ Agriculture and food security } & $\begin{array}{l}\text { Silting or destruction of small dams and pans, especially in ASALs used for } \\
\text { irrigation or watering points for livestock }\end{array}$ \\
\hline & & Losses of crops and stock from heavy rains and floods \\
\hline & & $\begin{array}{l}\text { Floods leach soils rendering them infertile resulting in poor yield. Floods } \\
\text { also cause physical damage to crops thus affecting the final yields }\end{array}$ \\
\hline & & $\begin{array}{l}\text { Floods kill livestock and promote outbreak of killer diseases such as pneumonia, } \\
\text { rift valley fever and the blue tongue }\end{array}$ \\
\hline & & Floods cause soil nutrient leaching and actual vegetation death due to root suffocation \\
\hline & & $\begin{array}{l}\text { When livestock is adversely affected, food security is threatened due to loss of the } \\
\text { industry's food contribution in terms of livestock and livestock products }\end{array}$ \\
\hline & \multirow{4}{*}{$\begin{array}{l}\text { Water, aquatic ecosystems } \\
\text { and associated infrastructure }\end{array}$} & $\begin{array}{l}\text { Extensive damage to water supply and sanitation infrastructure, including pipelines } \\
\text { and pumping stations }\end{array}$ \\
\hline & & dams overtopping due to extreme flooding \\
\hline & & Excessive river sedimentation \\
\hline & & $\begin{array}{l}\text { Coastal erosion, excessive siltation as well as Inundation of coastal wetlands causing } \\
\text { major disruption of functions of important aquatic ecosystems including coral reefs; } \\
\text { mangroves; seagrass/seaweed Beds; estuaries, deltas and lagoons }\end{array}$ \\
\hline
\end{tabular}

Food shortages from crop losses affects children's health

Floods Increased incidence of water-borne diseases following flooding

Health including sanitation and human settlement
Physical injury and death

Increased cases of diarrhea diseases due to inadequate portable water or contamination of water sources

Destruction of public and primary healthcare facilities

Human settlements and infrastructure being destroyed

Long-term effects on mental health and people may experience anxiety or depression for some time after a flood disaster

Likelihood of flood waters uprooting power poles

Likelihood of flood water uprooting trees which in turn fall on power lines

Likelihood of floods disrupting normal production and distribution of essential petroleum products such as cooking gas and other fuels to isolated areas that heavily

Energy and relevant infrastructure rely on such commodities for their energy supply as a result of roads being impassable

Floods will lead to increased sedimentation and hence frequent breakdowns of turbines at the power stations, causing frequent power cutting and therefore reduced industrial activity. Such floods are also destructive to both animal and plant life, which translates to a reduction in biomass production (note that over $80 \%$ of energy used in Kenya for domestic activities is biomass based)

Terrestrial ecosystem including forestry and Tourism
Destruction of infrastructure used by tourism industry(especially roads)

Damage to ecosystems on which tourism depends (e.g. Coral reefs) 


\section{Continued}

Agriculture and food security Drought leads to poor and inadequate pasture resulting in loss of livestock body condition due to insufficient feed. Nomadic pastoralists therefore move with livestock out of their normal grazing areas in search of pasture and water Loss of livestock, especially in ASALs

Additional costs of livestock maintenance, veterinary costs, supplemental feeding, etc.

Increased production of fish, adding to overfishing

Reduction in fish production from aquaculture

When fish is adversely affected, food security is threatened due to loss of their food contribution

Increase in the cost of vendor-supplied water in urban areas; more time spent queuing

Increased time spent searching for water in rural areas

Water, aquatic ecosystems and associated infrastructure

Droughts
Increased pumping of groundwater in urban areas leading to reduction in borehole yields

Iincrease in irrigation water demands possibly leading to conflicts in water use rights

A drop in water level in dams and rivers could adversely affect the quality of water by increasing the concentrations of sewage waste and industrial effluents, thereby reducing the quality and quantity of fresh water available for domestic use A drop in water level in dams and rivers could adversely affect the quality of water by increasing the concentrations of sewage waste and industrial effluents, thereby increasing the potential for the outbreak of diseases Management of pollution, sanitation, waste disposal, water supply, and public health, as well as provision of adequate infrastructure in urban areas, could become more difficult and costly under reduced water availability

Health including sanitation and human settlement

Reduction in food production leading to famine and deaths

Malnutrition or diseases will increase as a result of reduced immunity

Signs of protein-energy malnutrition such as weakness, weight loss and reduced mobility likely to be experienced

Cases of food toxicity likely since starving people will be tempted to consume unfamiliar foods without taking necessary precautions

Cases of Marasmus and Kwashiorkor will therefore be prevalent

Reduced hydropower production from low water levels

Energy and relevant infrastructure

Likelihood of importing higher-cost power from neighbors and provision of replacement generators

Loss of income from industries that lead to reduced production because of power shortages

Cost of desalinating groundwater in coastal areas, where seawater has intruded into aquifers

Terrestrial ecosystem including forestry and Tourism droughts and/or reduction in precipitation would devastate wildlife and reduce the attractiveness of some nature reserves, thereby reducing income from current vast investments in tourism

Increased tree loss from illegal felling, fires, grazing, diseases 


\subsection{Evaluation of the Existing Policies and Capacities to Address the Vulnerability}

\subsubsection{Policy and Intuitional}

Initially, the country lacked coordinated institutional structures and arrangements to mitigate the negative impacts of climate induced disasters. Lack of advance flood warning for example takes the public unaware, leaving no lead time to take preventative measures. In the absence of such a policy and legislation to act as a management tool and ensure effective response to disasters including flood, flood risk management in Kenya has remained largely inconsistent, uncoordinated and reactive as opposed to taking a more proactive approach [16]. This was evident during the El Niño floods of 1997/98 that was rather slow and uncoordinated despite the warnings that were issued prior to the event. However, the recently developed Draft disaster Management Policy together with the Climate Change Act [17] have spelt out clearly the institutional arrangements for effective response to climate induced disasters including early warnings. In fact recently, a National Disaster Management Authority (NDMA) was established for the purpose and is currently putting the relevant structures in place.

\subsubsection{Financial, Human and Technical Resources}

Financial, human and technical resources for sustainable disaster management measures have always been scarce in developing countries like Kenya. Such resources are a very important part of institutional arrangements. Lack of these resources limits the country's responsiveness to climate induced disasters. Many institutions charged with the responsibility of handling such disasters in the country are faced with inadequate budgetary allocations. Inadequate skilled human resources such as flood risk managers and modern gauging stations to monitor flood levels also hampers the process of flood risk management in the country.

\subsubsection{Community Participation and Sensitization}

The Kenyan community has not been sufficiently sensitized on disaster management including for example flood risk management in the country's floodprone regions. Lack of flood risk information at the community level especially, in preparedness and coping mechanisms is a major setback to long-term flood risk reduction strategies. For instance, river in e communities are not informed on the importance of maintaining dykes in dry seasons to avoid flooding during wet seasons. The communities are also left with no options of where to evacuate to in the event of a flood. This is further aggravated by high population that forces people to invade river banks due to pressure on scarce land.

\subsubsection{Infrastructural}

There are significant institutional weaknesses that pose major infrastructural challenges. For instance, there is a limited hydrological observation stations to monitor flood levels. Over the years, there has been a deterioration in the condition of the river gauging stations due to lack of regular repairs and preventative maintenance after major flood events such the 1998/98 El Niño flood. Automatic 
data sensors also lack frequent recalibration.

\section{Conclusion and Recommendations}

\subsection{Conclusion}

This study has revealed that Kenya is vulnerable to the impacts of climate variability and change. The vulnerability, however, varies across the country depending on the degree of exposure, sensitivity and adaptive capacities of systems in the respective areas of the country. Floods and drought account for the greatest impacts which have resulted in enormous economic losses, destruction of property and loss of lives as well as livelihoods. The country therefore, urgently needs to put in place a raft of measures (in terms of policies, regulations and institutions) that will minimize the exposure of systems as well as enhance the adaptive capacities.

\subsection{Recommendations}

1) Despite the many and varied negative impacts, climate change also presents opportunities to government, businesses and the public at large. Above all, climate change represents an opportunity to catalyze realignment of Kenya's development model to one that is climate resilient, based on lower GHG emissions and takes full advantage of the green economy. By focusing on vulnerable groups and building resilience, development can be achieved that simultaneously addresses poverty, food insecurity and unemployment concurrently with climate change.

2) Climate finance flows and carbon assets mechanisms present an opportunity to access new and additional levels of funding. For government, this means accessing international financing for ambitious climate resilient and low emission development programmes while for the private sector this can entail engaging in projects to generate carbon credits for sale in international markets, exploiting new green economy opportunities and the creation of green jobs.

3) The introduction of a devolved system of government provides a new opportunity to reorganize climate change governance by ensuring the climate change responses are mainstreamed into the functions of the national and county levels of government, and by facilitating the effective participation of citizens in climate change governance.

4) There is need to enhance the human capacity both at the technical and community level. More officers capable of monitoring climate parameters and incidences of natural disasters should be posted in the counties. These officers should work closely with those in the meteorological services. Existing institutions with expertise in climate and water resources monitoring should develop training modules aimed at enhancing capacity among staff working in sectors impinging on water resources and relevant sectors.

\section{Acknowledgements}

The author would like to thank all the institutions and personnel who in one 
way or another played a role in ensuring the relevant data used in this study was availed. I commend my fellow researchers at the Institute for Meteorological Training and Research for their constant encouragement as I continued to develop this paper. Last but not least, my sincere gratitude goes to the anonymous reviewer(s) whose comments considerably improved the manuscript.

\section{References}

[1] Government of Kenya (GoK) (2015) The Second National Communication to the UNFCCC. 212 p.

[2] Government of Kenya (GoK) (2011) County Fact Sheets. Summary by the Kenya Commission on Revenue Allocation.

[3] Pedreros, D. and Tamuka, M. (2016) FEWS NET GeoCLIM v1.1.2 Manual. 71 p.

[4] Climate Network Africa (1997) Potential Impacts of Climate Change in Kenya. Motif Creative Arts Ltd., Nairobi.

[5] DMCN (2002) Factoring of Weather and Climate Information and Products into Disaster Management Policy in Kenya. A Report of UNDP Sponsored Project.

[6] DMCN (2004) Traditional Indicators Used for Climate Monitoring and Prediction by Some Rural Communities in Western Kenya. A Pilot Project Report.

[7] Government of Kenya (GoK) (2012) Kenya Post-Disaster Needs Assessment (PDNA). 2008-2011 Drought, Report by the Ministry of Finance.

[8] World Bank (2005) Economic Impact of Rainfall Variability and Water Resources Degradation in Kenya. A World Bank Working Paper No. 69.

[9] Stockholm Environment Institute (SEI) (2009) Economics of Climate Change in Kenya. A SEI Project Report.

[10] DMCN (2004) Impacts, Vulnerability Assessment and Adaptation Options in the Flood Prone Areas of Western Kenya. A Report of UNEP Sponsored Project.

[11] Kebede, A.S., Hanson, S., Nicholls, R.J. and Mokrech, M. (2009) Impacts of Climate Change and Sea Level Rise: A Case study of Mombasa, Kenya.

[12] Otiende, B. (2008) Risk Assessment for Extreme Riverine Floods in Kenya. A Tool for Flood Risk Management.

[13] Aklilu, Y. and Wekesa, M. (2001) Livestock and Livelihoods in Emergencies: Lessons Learnt from the 1999-2001 Emergency Response in the Pastoral Sector in Kenya. OAU-IBAR, Kenya and Feinstein International Famine Centre, USA.

[14] Government of Kenya (GoK) (1998) Flood Damage Costs for Water Sector. Government Report.

[15] UNEP/GoK (2000) Devastating Drought in Kenya: Environmental Impacts and Responses. A Report of the UNEP, Nairobi.

[16] Karanja, F., Ogallo, L.J., Mutua, F.M., Oludhe, C. and Kisia, S. (2002) Impacts and Response to the 1997-1998 El Niño Event. Kenya Country Case Study.

[17] Government of Kenya (GoK) (2016) Climate Change Act. Kenya Gazette Supplement No. 68 (Acts No. 11). 
Submit or recommend next manuscript to SCIRP and we will provide best service for you:

Accepting pre-submission inquiries through Email, Facebook, LinkedIn, Twitter, etc. A wide selection of journals (inclusive of 9 subjects, more than 200 journals)

Providing 24-hour high-quality service

User-friendly online submission system

Fair and swift peer-review system

Efficient typesetting and proofreading procedure

Display of the result of downloads and visits, as well as the number of cited articles Maximum dissemination of your research work

Submit your manuscript at: http://papersubmission.scirp.org/

Or contact ajcc@scirp.org 